\title{
PENGEMBANGAN PROGRAM POSYANDU LANSIA DENGAN APLIKASI PENDEKATAN PROGRAM PENGELOLAAN PENYAKIT KRONIS (PROLANIS) DI WILAYAH KERJA PUSKESMAS RANCAEKEK (STUDI KUALITATIF)
}

\author{
Erlina Fazriana ${ }^{1}$, Oktarian Pratama ${ }^{2}$ \\ erlina.fazriana@yahoo.com \\ ${ }^{1}$ Program Studi Sarjana keperawatanSTIKes Dharma Husada Bandung \\ ${ }^{2}$ Program Studi Diploma Tiga keperawatanSTIKes Dharma Husada Bandung,
}

\begin{abstract}
ABSTRAK
Program pengelolahan penyakit kronis (Prolanis) adalah suatu sistim pelayanan kesehatan dan pendekatan proaktif yang di laksanakan secara terintegrasi yang melibatkan peserta, fasilitas kesehatan dan BPJS. Berdasarkan informasi dari Kepala Puskesmas Rancaekek, bahwa program lansia yang diselenggarakan di lingkungan Puskesmas Rancaekek untuk program posyandu lansia sudah diberlakukan pendekatan program yang bekerjasama dengan BPJS yaitu program pengelolaan penyakit kronis (Prolanis) sejak Jaminan Kesehatan Nasional (JKN) mulai diberlakukan di Indonesia yaitu sejak awal tahun 2015. Tujuan Penelitian ini adalah untuk mendapatkan gambaran makna dari pengembangan program posyandu lansia dengan aplikasi pendekatan program pengelolaan penyakit kronis (Prolanis) di wilayah Puskesmas Rancaekek. Jenis penelitian kualitatif dengan metode fenomenologi deskriptif. Sampel informan dalam penelitian ini dipilih berdasarkan teknik sampling purposive sampling. informannya adalah pemegang program lansia di puskesmas tersebut dan 4 orang Kader di wilayah Puskesmas Rancaekek. Instrumen penelitian yang digunakan adalah pedoman wawancara (indepth interview), data observasi, alat perekam dan buku catatan lapangan. Uji validitas pada penelitian kualitatif ini dilakukan dengan Triangulasi. Analisa data dilakukan dengan cara analisa deskriptif. Hasil penelitian yang didapatkan dari hasil wawancara dengan tema evaluasi input: bertambahnya jumlah kader Posyandu lansia yang datang dan bertambahya dukungan pembiayaan dari BPJS Kesehatan, evaluasi proses: belum melaksanakan 10 jenis layanan dan belum menerapkan sistem 5 meja sesuai standar pelaksanaan Posyandu Lansia dari Kemenkes RI namun dalam pelaksanaannya tenaga kesehatan professional sudah dilibatkan, evaluasi output: kurangnya cakupan kunjungan lansia namun dampak dari pelaksanaan PROLANIS terlihat ada perubahan perilaku pengendalian penyakit kronis (Hipertensi dan DM) serta peningkatan kualitas hidup lansia. Saran bagi tenaga kesehatan mengoptimalkan kuantitas pelayanan Posyandu lansia dengan selalu melaksanakan 10 jenis layanan posyandu lansia dan menggunakan tahapan 5 meja dalam pelaksanaan posyandu lansia.
\end{abstract}

Kata Kunci : Pengembangan program, PROLANIS

\section{PENDAHULUAN}

Badan kesehatan dunia WHO menyatakan bahwa penduduk lansia di Indonesia pada tahun 2020 mendatang akan mencapai angka $11,34 \%$ atau tercatat 28,8 juta orang dan menjadikan jumlah penduduk lansia di Indonesia menjadi terbesar ke empat di dunia 
setelah Cina, Amerika, dan India (BPS, 2009). Layanan kesehatan yang semakin menjangkau rakyat banyak berakibat meningkatnya angka rata-rata harapan hidup orang Indonesia yakni tahun 2011 menjadi 67,07 dengan usia harapan hidup laki-laki 65,21 dan usia harapan hidup perempuan 69,05 (Menko Kesra,2011). Propinsi Jawa Barat menempati urutan ke lima yang paling banyak penduduk lansia di Indonesia. Yang paling terbesar adalah Yogyakarta $(12,48 \%)$ menyusul Jawa Timur $(9,36 \%)$ di urutan kedua dan Jawa Tengah $(9,26 \%)$ di urutan ketiga, dan Bali $(8,77 \%)$ di urutan ke empat, serta Jawa Barat $(7,09 \%)$ di posisi ke lima dari total jumlah lansia di Indonesia (BPS, 2009). Seiring dengan semakin meningkatnya populasi lansia, pemerintah telah merumuskan berbagai kebijakan pelayanan kesehatan usia lanjut yang ditujukan untuk meningkatkan derajat kesehatan/mutu kehidupan lansia untuk mencapai masa tua bahagia dan berdaya guna dalam kehidupan keluarga/masyarakat sesuai dengan keberadaannya. Di pelayanan kesehatan tingkat masyarakat ada Posyandu lansia, sedangkan untuk pelayanan kesehatan lansia tingkat dasar adalah Puskesmas, dan pelayanan kesehatan tingkat lanjutan adalah Rumah Sakit (Fallen, 2010).
Posyandu lansia merupakan wahana pelayanan bagi kaum usia lanjut yang dilakukan dari, oleh dan untuk kaum usia lanjut yang menitikberatkan pada pelayanan promotif dan preventif, tanpa mengabaikan upaya kuratif dan rehabilitatif. Kegiatannya adalah pemeriksaan kesehatan secara berkala, peningkatan olahraga, pengembangan keterampilan, bimbingan pendalaman agama, dan pengelolaan dana sehat (Departemen Kesehatan, 2008). Sedangkan program pengelolahan penyakit kronis (Prolanis) adalah suatu sistim pelayanan kesehatan dan pendekatan proaktif yang di laksanakan secara terintegrasi yang melibatkan peserta, fasilitas kesehatan dan BPJS. Penyakit Kronis yang di alami oleh masyarakat dewasa ini, akan memberikan dampak dan beban bagi keluarga, bila penanganan di lakukan secara tidak intesif dan berkelanjutan. Manfaat penanganan yang intesif bagi penderita, adalah dapat mengenal tanda bahaya, dan tindakan segera bila mengalami kegawatdaruratan

Pelaksanaan posyandu lansia dan prolanis di puskesmas perlu dilakukan dengan manajemen yang baik dengan memperhatikan aspek perencanaan, pelaksanaan, pemantauan dan evaluasi. Penilaian keberhasilan program harus 
dimulai dari awal kegiatan yang meliputi masukan, proses, dan keluaran dengan aspek teknis dan manajerial termasuk penyediaan sarana, prasarana, dan informasi yang digunakan untuk perencanaan lebih lanjut (Departemen Kesehatan, 2008).

Posyandu lansia dan prolanis banyak memberikan manfaat bagi lansia yang mengikutinya. Apabila program Posyandu lanisia dan prolanis tidak terlaksana maka kegiatan pembinaan kesehatan lansia, pencatatan dan pelaporan status kesehatan lansia, proses monitor kesehatan lansia melalui pemeriksaan lansia, pengkajian indeks kemandirian dan indeks masa tubuh lansia, upaya preventif terhadap status kesehatan lansia secara berkala, tidak dapat terlaksana.

Adapun beberapa kendala
pelaksanaan posyandu lansia serta
prolanis, misalnya: pengetahuan lansia
yang rendah tentang manfaat Posbindu
sehingga lansia tidak datang ke Posbindu
karena mereka merasa keadaan kesehatan
baik. Kurangnya dukungan sosial / keluarga yang mengakibatkan lansia kurang termotivasi untuk datang rutin ke Posbindu. Kesan yang buruk terhadap petugas Posbindu sehingga lansia tidak mempunyai kesiapan untuk menghadiri kegiatan di Posbindu. Jarak rumah dengan lokasi Posbindu yang jauh / tidak terjangkau menjadikan lansia malas datang ke Posbindu karena terjadinya kelelahan fisik ataupun kekhawatiran dalam perjalanan menuju lokasi Posbindu.

Dalam penelitian Sutini (2010) ada beberapa faktor yang menjadi kendala pada posyandu lansia seperti pengetahuan lansia yang rendah tentang manfaat posyandu, jarak rumah dengan lokasi posyandu yang jauh dan sulit dijangkau, dukungan keluarga yang kurang, sikap kader/petugas kesehatan, pihak pemerintah/institusi, keterampilan kader serta ada tidaknya sarana dan prasarana yang dibutuhkan.

Evaluasi pengembangan program posyandu lansia sangat penting untuk dilakukan. Dengan melakukan evaluasi pengembangan program posyandu lansia yang ada di masyarakat, bisa diketahui kekurangan dan kelebihan program posyandu lansia yang akhirnya bisa menentukan apakah program yang telah dilaksanakan dapat mencapai hasil yang sudah ditentukan. Evaluasi program dapat digunakan sebagai bahan pertimbangan bagi pengambil keputusan dalam menentukan alternatif kebijakan dengan mengetahui seberapa tinggi mutu suatu program sebagai hasil dari pelaksanaan 
program yang dibandingkan dengan standar yang sudah ada (Azwar, 1996).

Berdasarkan informasi dari Kepala Puskesmas Rancaekek, bahwa program lansia yang diselenggarakan di lingkungan Puskesmas Rancaekek untuk program posyandu lansia sudah diberlakukan pendekatan program yang bekerjasama dengan BPJS yaitu program pengelolaan penyakit kronis (Prolanis) sejak Jaminan Kesehatan Nasional (JKN) mulai diberlakukan di Indonesia yaitu sejak awal tahun 2015.

\section{METODE PENELITIAN}

Jenis penelitian kualitatif dengan metode fenomenologi deskriptif. Sampel informan dalam penelitian ini dipilih berdasarkan teknik sampling purposive sampling. Sampel dalam penelitian ini adalah Puskesmas yang melaksanakan program posbindu dengan aplikasi program lansia kronis (PROLANIS) dan informannya adalah pemegang program lansia di puskesmas tersebut dan 4 orang Kader di wilayah Puskesmas Rancaekek. Data dikumpulkan melalui wawancara mendalam (indepth interview), observasi dan telaah dokumen. Wawancara mendalam diltujukan kepada 1 orang pemegang program lansia di Puskesmas Rancaekek dan 4 orang kader yang melaksanakan program posbindu dengan aplikasi pendekatan program lansia kronis (PROLANIS). Instrumen penelitian yang digunakan adalah pedoman wawancara, data observasi, alat perekam dan buku catatan lapangan. Data tersebut diperoleh dengan melakukan wawancara secara mendalam kepada 1 orang pemegang program lansia di Puskesmas Rancaekek dan 4 orang kader posbindu meliputi pengumpulan data tentang kesiapan sumber daya manusia, fasilitas, pendanaan, sosialisasi kegiatan dan evaluasi dari setiap puskesmas. Pengolahan data dimulai dengan mentranskripsikan seluruh data secara utuh berdasarkan kelompok topik, dikembangkan ke bentuk bahasa yang lebih baku, secara naratif dan kemudian direduksi dalam bentuk rangkuman. Analisa data dilakukan dimulai dengan pengumpulan data, reduksi data, menyajikan data dan menarik kesimpulan dan verifikasi. Validitas pada penelitian kualitatif ini dilakukan dengan Triangulasi.

\section{HASIL DAN PEMBAHASAN}

Wilayah kerja Puskesmas Rancaekek ini terdapat 7 Posyandu Lansia yang terdapat di masing - masing Kelurahan/Desa. Tempat dan jadwal yang ditetapkan dapat berubah-ubah dan tidak tetap apabila ada halangan pada petugas 
atau tanggal yang ditetapkan jatuh pada hari libur. Jarak Posyandu Lansia yang dekat dengan Puskesmas Induk (Puskesmas Rancaekek) adalah Posyandu Lansia Kencana, Posyandu Lansia Bojong Dan Posyandu Lansia Kencana mukti sedangkan empat Posyandu Lansia lainnnya berada jauh $+2-7 \mathrm{~km}$ dari Puskesmas Induk. Berdasarkan hasil observasi, wawancara mendalam dan rekap laporan yang dilakukan peneliti diperoleh bahwa kunjungan Posyandu Lansia di tujuh Desa/Kelurahan ini masih sangat rendah karena hanya 16,29\% dari jumlah sasaran. Kondisi ini disebabkan oleh banyaknya lansia yang kurang percaya dengan pemeriksaan di Posyandu Lansia karena petugas kesehatan yang memeriksa hanya perawat dan bidan saja sementara para lansia sangat mengharapkan agar di Posyandu Lansia juga ada dokter. 1 Posyandu Lansia sudah mengaplikasikan PROLANIS ke dalam pelaksanaan Posyandu Lansia dari bulan April 2015. Hasil wawancara mendalam didapatkan transkripsi wawancara sebanyak 24 halaman. Dari hasil transkripsi lalu dilakukan reduksi untuk kemudian dilakukan koding dan kategorisasi. Dibawah ini dibuat kode informan yang disajikan sebagai berikut:
Tabel 1. Data dan Kode Informan PKM Rancaekek dekat pedesaan

\begin{tabular}{ccc}
\hline No & Kode & Keterangan \\
\hline $\mathbf{1}$ & Bd. B & $\begin{array}{c}\text { Pemegang } \\
\text { Program Lansia di } \\
\text { Puskesmas }\end{array}$ \\
& & Rancaekek \\
$\mathbf{2}$ & Kd. 1B & Kader \\
$\mathbf{3}$ & Kd. 2B & Kader \\
$\mathbf{4}$ & Kd. 3B & Kader \\
$\mathbf{5}$ & Kd. 4B & Kader \\
\hline
\end{tabular}

\section{1) Input}

Hasil penelitian mengenai evaluasi input didapatkan beberapa tema penting diantaranya adalah kesiapan sarana, obat dan SDM, serta dukungan pembiayaan. Berikut hal yang didapatkan dari hasil wawancara dengan informan tersebut.

Berdasarkan hasil wawancara mendalam terkait dengan kesiapan sarana, obat dan SDM sebagai berikut:

"Untuk perlengkapan sarana dan obat-obatan yang dimiliki saat ini semenjak ada prolanis kita mendapatkan suntikan dana dari BPJS untuk melengkapi sarana dan obat-obatan. sarana yang kita punya ada meja dan kursi, alat tulis, buku pencatatan kegiatan, timbangan dewasa, stetoskop, tensimeter, dan Kartu Menuju Sehat (KMS) lansia, sedangkan untuk obat-obatan dibawa dari puskesmas, palingan obat penurun tekanan darah sama pengontrol gula darah “......(Bd. A)

"Kita ada KMS lansia, meja dan kursi, timbangan, dan buku catatan, kalau obat-obatan yang saya tahu paling sering dibawa petugas puskesmas obat jantung pak”.....(Kd. 5A) 
"Sarana dan obat-obatan yang dimiliki kebanyakan dibawa dari puskesmas. Untuk sarana yang kita punya hanya meja dan kursi, alat tulis, buku pencatatan kegiatan, timbangan dewasa, stetoskop, tensimeter, dan Kartu Menuju Sehat (KMS) lansia “.......(Bd. B)

"Lumayan lah pak. kita punya KMS lansia,tensimeter, timbangan dan buku pencatatan kegiatan”...(Kd. 3B)

Berdasarkan hasil wawancara di atas terlihat bahwa dari aspek sarana dan obatobatan sudah sangat memadai dibandingkan sebelum mengaplikasikan PROLANIS. Dengan bantuan dana dari BPJS kelengkapan sarana dan obatobatan bisa dilengkapi. Sementara itu, untuk kesiapan SDM mayoritas yang menjadi kader sudah dilatih. Hal tersebut dapat terlihat dari hasil wawancara berikut:

"Kalau yang sudah dilatih sebenarnya semua kader sudah dilatih. Waktu itu pelatihan tentang pelaksanaan Posyandu Lansia dari dinas kesehatan langsung, hanya saja yang sudah dilatih belajar tensi hanya 2 orang,yaitu bu nining dan bu imas karena mereka kader yang paling lama disini”.... (Bd. A)

"Jumlah keseluruhan kader ada 6 kader. tapi hanya ada 4 kader yang sudah dilatih dan selalu aktif pada saat pelaksanaan posbindu”.....(Kd. 4A)
"“Jumlah kader secara keseluruhan sebenarnya ada 5 hanya saja cuma 3 orang yang aktif,yaitu bu imas,bu nurul dan bu nining”.....(Kd. 1B)

"Untuk kader di Posyandu Lansia $R W 8$ ini dapat dirasa sudah baik, karena jumlah serta kualitas/kompetensi yang dimiliki kader dalam pelaksanaan program Posyandu Lansia sudah seimbang. Kita sudah memiliki 7 orang kader, jumlah tersebut dirasa cukup dan tidak memberatkan para kader dalam menjalankan tugasnya hanya saja yang aktif dan sering mendapatkan pelatihan hanya 3-5 orang"....... (Bd. B)

"Kalau kendala sebenarnya hanya di masalah umur mungkin pak, karena Puskesmas Rancaekek mensyaratkan untuk menjadi kader Posyandu Lansia, mereka harus berasal dari lansia itu sendiri. Namun menurut saya kader yang sudah ada sudah memiliki kompetensi dalam memberikan pemeriksaan kesehatan kepada lansia seperti halnya mengukur tekanan darah dengan menggunakan tensimeter. Namun pemeriksaan kesehatan yang dilakukan para kader kepada lansia seperti itu perlu pendampingan dari petugas medis yaitu petugas puskesmas. Para kader disini sudah mendapat pelatihan-pelatihan yang diberikan oleh Dinas Kesehatan Kabupaten Banadung sebelum dijadikan sebagai kader sehingga mampu melakukan pemeriksaan kepada lansia. Para kader juga telah masuk dalam kualifikasi menjadi seorang kader Posyandu Lansia, yang salah satu kualifikasinya adalah berasal dari anggota 
masyarakat $R W \quad 8 \quad$ sendiri. Meskipun ada salah satu atau 3 kader yang tidak pernah aktif.".......(Bd. B)

Berdasarkan hasil wawancara di atas terlihat bahwa Secara keseluruhan kader Posyandu Lansia tidak ada kendala, banyak yang sudah dilatih dan aktif menjadi kader. Masalah hanya ada di umur saja karena aturan yang mengharuskan kader berasal dari lansia.

Kemudian, untuk masalah mengenai dukungan pembiayaan Posyandu Lansia baik dari masyarakat, pemerintah dan lembaga donor dapat terlihat dari hasil wawancara berikut:

"dulu sebelum ada prolanis untuk dukungan pembiayaan lebih banyak dari masyarakat itu sendiri pak, biasanya setiap ada Posyandu Lansia mereka nyumbang secara sukarela atau kita sebut "kenclengan", sedangkan dari pemerintah dan dari sponsor belum ada, sedangkan semenjak adanya program PROLANIS kita mendapatkan bantuan dana dari BPJS"....(Bd. A)

"Untuk pembiayaan kita patungan dari peserta Posyandu Lansia yang datang. Jadi setiap lansia yang datang ke Posyandu Lansia memberikan sumbangan secara sukarela, sedangkan dana dari pemerintah kita meminta jatah $20 \%$ dari dana bantuan pelaksanaan posyandu yang kegiatannya dilaksanakan berbarengan pada pelaksanaan Posyandu Lansia. Selain itu kita juga ada bantuan dana dari BPJS” .....(Bd. B)
"Dalam pembiayaan memang masih ada kendala...Kendala yang dirasakan mungkin dikarenakan Peran Puskesmas Rancaekek belum terlihat dalam biaya operasional Posyandu Lansia,dan hanya mengandalkan iuran warga dan terkadang dari sumbangan desa, hal itu mungkin menjadi kendala untuk membiayai Posyandu Lansia dan melaksanakan Posyandu Lansia sesuai peraturan menteri kesehatan tentang Posyandu Lansia hanya saja memang beberapa bulan belakangan ini kita terbantu dengan adanya PROLANIS dalam hal pembiayaan”......(Kd. 4B)

Berdasarkan hasil wawancara di atas terlihat bahwa dukungan pembiayaan menunjukkan sudah ada kesadaran dari masyarakat terkait pelaksanaan Posyandu Lansia. Ditambah bantuan biaya dari pihak BPJS dengan berjalannya PROLANIS. Hal tersebut terlihat dari Posyandu Lansia yang menyatakan bahwa salah satu upaya dalam pembiayaan yaitu mereka melakukan kenclengan atau patungan untuk pembiayaan. Selain itu, bantuan dari BPJS sangat membantu dalam penatalaksanaan penyakit Hipertensi dan DM.

\section{2) Process}

Hasil penelitian mengenai evaluasi proses didapatkan beberapa tema penting diantaranya adalah jenis layanan yang diberikan, partisipasi masyarakat, 
kapasitas pemantauan perkembangan

lansia. Berikut hal yang didapatkan dari hasil wawancara dengan informan tersebut.

"Sejauh ini untuk layanan yang sudah diberikan baik itu pengobatan gratis, senam lansia semuanya mendapat respon positif dari masyarakat, hanya saja mungkin mereka lebih memilih jenis layanan pengobatan gratis untuk datang ke Posyandu Lansia. Untuk pemeriksaan gula darah, tekanan darah.terutama pada pelaksanaan PROLANIS”.....(Bd. A)

"Partisipasi masyarakat untuk Posyandu Lansia bisa dibilang meningkat semennjak PROLANIS dijalankan, bisa dilihat dari jumlah kader yang tadinya berjumlah 2 orang sekarang menjadi 4 orang. Selain itu capaian kedatangan lansia dan pra lansia lebih baik dari bulan- bulan sebelumnya”....(Bd. A)

"Selama ini pemantauan perkembangan lansia dilakukan menggunakan KMS lansia. Hanya saja belum dilakukan secara periodik. Selain itu Penjaringan penyakit pada lansia juga telah dilakukan, baik oleh petugas kesehatan di puskesmas maupun kader yang telah dilatih dalam pemeliharaan kesehatan lansia”.....(Bd. A)

"Untuk jenis kegiatan kita ada pengukuran tekanan darah, ukur tinggi badan, timbang berat badan, dan kadang-kadang ada pengobatan gratis juga .. dan sejauh ini semuanya berjalan baik pak.. selain itu terkadang ada pengajian hanya saja tidak teratur pak juga tiap hari minggu pagi kita ada senam lansia berhubungan dengan pelaksanaan PROLANIS”.....(Bd. B)

Berdasarkan hasil wawancara didapatkan bahwa secara keseluruhan pelayanan yang diberikan mendapat respon positif, walaupun titik beratnya masih pada pengobatan. PROLANIS yang di aplikasikan ke dalam Posyandu Lansia membuat masyarakat semakin ramai untuk datang ke Posyandu Lansia. Perbaikan pelayanan perlu terus ditingkatkan, termasuk upaya promotif dan preventif. Partisipasi masyarakat masih belum merata dan cenderung partisipasinya rendah untuk aktif datang ke posyandu lansia kalau tidak sakit dan pemantauan perkembangan lansia menggunakan KMS Lansia perlu ditingkatkan.

\section{3). Output}

Hasil penelitian mengenai evaluasi Output didapatkan beberapa tema penting diantaranya adalah rata-rata jumlah kunjungan, dan faktor pendorong dan penghambat Posyandu Lansia. Berikut hal yang didapatkan dari 
hasil wawancara dengan informan tersebut.

"sebelum ada PROLANIS rata-rata Lansia yang datang ada 10-20 orang yang datang tapi ada juga yang hanya 5orang saja tetapi semenjak diberlakukannya PROLANIS cakupan kedatangan lansia mencapai 40-60 orang setiap kali pelaksanaan Posyandu Lansia....ngak tahu kenapa bisa begitu”.... (Kd.1A)

"Untuk faktor pendorong mungkin untuk rutin memeriksakan kesehatannya dan diaplikasikan PROLANIS menambah semangat mereka untuk datang ke Posyandu Lansia. kalau faktor penghambatnya mungkin jaraknya yang jauh atau lupa mungkin pak”.....(Bd. A)

"Rata-rata ada 40-50 orang yang datang tapi ada juga yang hanya 30 orang saja yang datang”.....(Kd. $4 \mathrm{~A})$

"Kalau dari pengamatan saya sih....yang mendorong mereka untuk datang ke Posyandu Lansia dan memanfaatkan Posyandu Lansia itu karena kondisi kesehatan mereka ....namun penghambatnya adalah karena faktor lupa....mereka sering sekali lupa...selain itu ada juga yang sibuk dengan pekerjaannya menjaga сиси”......(Bd. A).

Berdasarkan hasil wawancara didapatkan bahwa rata-rata kunjungan lansia masih belum merata, walaupun memang mengalami peningkatan semenjak ada PROLANIS. Faktor pendorong lansia datang ke Posyandu Lansia yaitu terkait kondisi kesehatan lansia saya pada intinya ingin berobat, penghambat ada jarak, kesibukan dan lainnya. Secara keseluruhan perlu ada pemahaman yang sama baik dari petugas kesehatan, kader dan masyarakat mengenai Posyandu Lansia, bahwa Posyandu Lansia bukan pelayanan bagi yang sedang sakit saja tetapi tujuan utamanya untuk pencegahan dan peningkatan derajat kesehatan lansia.

\section{Hasil Observasi}

\section{1) Input}

Berdasarkan hasil observasi lapangan didapatkan untuk jenis tenaga kesehatan yang datang pada saat pelaksanaan Posyandu Lansia setelah pelaksanaan PROLANIS di wilayah kerja Puskesmas Rancaekek ada Dokter dan Bidan. Terkadang ada satu orang perawat dan satu orang petugas laboratorium yang datang pada saat pelaksanaan salah satu Posyandu Lansia.

Berdasarkan hasil observasi lapangan juga didapatkan sarana prasarana yang ada di tiap Posyandu Lansia. Posyandu Lansia 1 yang berada di wilayah kerja puskesmas Rancaekek sarana dan prasarana yang ada sudah lengkap yang dibantu oleh dukungan dana BPJS terhadap PROLANIS. Kegiatan dilaksanakan di Kantor PKK. 
Sarana yang ada terdapat meja dan kursi, alat tulis, buku pencatatan kegiatan (buku register), Kit lanjut usia (timbangan dewasa, meteran, Stetoskop dan tensimeter) dan Kartu Menuju Sehat (KMS) lansia sedangkan Buku Pedoman Pemeliharaan Kesehatan (BPPK) lanjut usia belum ada..

Berdasarkan observasi dilapangan Posyandu Lansia yang ada diwilayah kerja puskesmas Rancaekek belum memiliki sarana dan prasarana yang memadai seperti di Posyandu Lansia 1 tempat pelaksanaan Posyandu Lansia dilakukan di kantor PKK yang kalau hujan sering terkena banjir sehingga untuk pelaksanaan Posyandu Lansia tidak dilakukan menunggu air surut. Posyandu Lansia 2 dilaksanakan berpindah-pindah tempat antara sekolah dan gedung BPK desa sedangkan untuk sarana yanga ada di kedua Posyandu Lansia sama-sama memiliki meja dan kursi, alat tulis, buku pencatatan kegiatan, Kit lanjut usia dan KMS lansia. Masing-masing Posyandu Lansia tidak memiliki buku pedoman pemeliharaan kesehatan.

Berdasarkan observasi lapangan di semua Posyandu Lansia juga tidak ditemukan Standar Operasional Prosedur (SOP) pelaksanaan Posyandu lansia sesuai edaran dari Kementerian Kesehatan RI.

\section{2) Process}

Berdasarkan hasil observasi lapangan untuk mekanisme pelaksanaan kegiatan Posyandu Lansia semuanya sudah sesuai dengan tahapan pelaksanaan kegiatan yang ditetapkan oleh kementerian kesehatan RI, hanya saja untuk tahapan keempat yaitu pemeriksaan air seni dan kadar darah tidak satupun ditemukan di semua Posyandu Lansia di wilayah kerja Puskesmas Rancaekek. Sedangkan jenis layanan yang diberikan pada proses pelaksanaan Posyandu Lansia hanya 1 Posyandu Lansia yang melaksanakan 10 jenis kegiatan yang dianjurkan oleh Kementerian Kesehatan RI yaitu Posyandu Lansia 2 di wilayah kerja puskesmas Rancaekek . Evaluasi merupakan suatu proses yang dilakukan oleh seseorang untuk melihat sejauhmana keberhasilan sebuah program. Dalam keberhasilan ada dua konsep yang terdapat di dalamnya yaitu efektifitas dan efisiensi. Efektifitas merupakan perbandingan antara output dan input sedangkan efisiensi adalah taraf pendayagunaan input untuk menghasilkan output lewat suatu proses. Hasil penelitian dari Posyandu Lansia, menunjukkan bahwa program yang paling mereka inginkan adalah pengobatan gratis, padahal kalau kembali ketujuan pembentukan Posyandu Lansia 
adalah untuk pencegahan dan peningkatan derajat kesehatan lansia sehingga sejauh ini belum tercapai tujuan tersebut.

Dalam hal input banyak faktor yang menyebabkan belum optimalnya pelaksanaan Posyandu Lansia diantaranya belum siapnya keterdukungan dana dari pemerintah maupun pihak swasta. Salah satu upaya dalam pembiayaan yaitu mereka melakukan kenclengan atau patungan untuk pembiayaan dan ditambah bantuan dana dari BPJS Kesehatan yang sangat membantu dalam pengendalian penyakit Kronis. Sarana dan obat-obatan yang ada pada pelaksanaan Posyandu Lansia dengan Mengaplikasikan PROLANIS sudah lebih lengkap terlihat dari pada sebelumnya. Hal tersebut diperkuat dengan observasi dilapangan di Posyandu Lansia yang ada diwilayah kerja puskesmas Rancaekek yang sudah memiliki meja dan kursi, alat tulis, buku pencatatan kegiatan, Kit lanjut usia dan KMS lansia. Hanya buku pedoman pemeliharaan kesehatan yang belum dimiliki, padahal menurut Kemenkes (2010) untuk kelancaran pelaksanaan kegiatan Posyandu Lansia maka dibutuhkan sarana dan prasarana penunjang meliputi : tempat kegiatan (gedung, ruangan atau tempat terbuka), meja dan kursi, alat tulis, buku pencatatan kegiatan (buku register bantu), Kit lanjt usia (timbangan dewasa, meteran, stetoskop dan tensimeter, thermometer), Kartu Menuju Sehat (KMS) lansia, Buku Pedoman Pemeliharaan Kesehatan (BPPK) lanjut usia.

Ketidaksiapan SDM juga membuat pelaksaanaan Posyandu Lansia pada tahap input belum optimal. Berdasarkan hasil observasi lapangan didapatkan untuk jenis tenaga kesehatan yang datang pada saat pelaksanaan Posyandu Lansia di wilayah kerja puskesmas Rancaekek semuanya hanya bidan dan dokter. Terkadang hanya satu orang yang rutin ada yaitu bidan yang datang pada saat pelaksanaan salah satu Posyandu Lansia. Posyandu Lansia di wilayah kerja puskesmas Rancaekek Jumlah kader yang datang pada saat pelaksanaan Posyandu Lansia di kurang lebih ada 3-4 orang, padahal menurut buku panduan pelaksanaan posyandu lansia dari Kemenkes (2010) menyatakan bahwa untuk sekali pelaksanaan Posyandu Lansia dianjurkan minimal 5 orang kader yang datang.

Dalam hal Process berdasarkan hasil penelitian terlihat bahwa rata-rata kunjungan lansia ke Posyandu Lansia masih rendah walaupun mengalami peningkatan semenjak diaplikasikan 
PROLANIS. Mayoritas lansia yang datang hanya karena kondisi kesehatan yang sedang tidak baik saja. Artinya mereka masih menganggap bahwa Posyandu Lansia sebagai tempat untuk berobat. Dampaknya ketika mereka tidak mengalami keluhan kesehatan maka mereka tidak mau untuk datang ke Posyandu Lansia.

Hal tersebut dipertegas oleh keterangan dari Bidan Desa bahwa saat pelaksanaan program, lansia yang datang jauh dari target yang ditetapkan. Bidan mengatakan pula bahwa selain masyarakatnya yang masih rendah pemanfaatan Posyandu Lansia, kadernya juga sering menjadi kendala. Hal tersebut, terkait dengan peraturan dari Bupati Kabupaten Bandung bahwa kader posyandu lansia dianjurkan harus lansia juga sehingga untuk menggerakan supaya lebih aktif merasa kesulitan karena terkendala usia, kondisi fisik dan daya tangkap mereka juga dan akhirnya sampai saat ini pemanfaatan posyandu lansia masih sangat rendah.

Hal tersebut senada dengan penelitian Pertiwi bahwa pemanfaatan posyandu lansia oleh masyarakat sangat rendah. Lansia mau datang ke posyandu lansia apabila mengalami keluhan kesehatan. Penelitian Purnawati mengatakan hal yang sama yaitu rendahnya pemanfaatan posyandu lansia. Berdasarkan hasil observasi lapangan untuk mekanisme pelaksanaan kegiatan Posyandu Lansia semua Posyandu Lansia sudah sesuai dengan tahapan pelaksanaan kegiatan yang ditetapkan oleh kementerian kesehatan RI, hanya saja untuk tahapan keempat yaitu pemeriksaan air seni dan kadar darah tidak ditemukan.

Menurut Buku Pedoman Penyelenggaraan Posyandu lansia dari Kemenkes (2010) pemeriksaan pada saat pelaksanaan posyandu lansia meliputi :

1) Pemeriksaan aktivitas kegiatan sehari - hari, meliputi kegiatan dasar dalam kehidupan seperti makan, minum, berjalan, mandi, berpakaian, naik turun tempat tidur, buang air besar / kecil dan sebagainya.

2) Pemeriksaan status mental emosional dengan menggunakan pedoman 2 menit (lihat KMS lansia).

3) Pemeriksaan status. gizi melalui penimbangan berat badan dan pengukuran tinggi badan dan hasilnya dicatat pada grafik Indeks Masa Tubuh (IMT).

4) Pengukuran tekanan darah menggunakan tensimeter dan stetoskop serta penghitungan denyut nadi selama satu menit. 
5) Pemeriksaan hemoglobin dengan menggunakan Talquist, Sahli atau Cuprisulfat.

6) Pemeriksaan adanya gula dalam air seni sebagai deteksi awal adanya penyakit gula (Diabetes Melitus).

7) Pemeriksaan adanya zat putih telur (protein) dalam air seni sebagai deteksi awal adanya penyakit ginjal.

8) Pelaksanaan rujukan ke puskesmas bilamana ada keluhan dan atau ditemukan kelainan pada pemeriksaan butir 1 sampai 7 .

9) Penyuluhan bisa dilakukan didalam maupun diluar kelompok dalam rangka kunjungan rumah dan konseling kesehatan dan gizi sesuai dengan masalah kesehatan yang dihadapi oleh individu dan atau kelompok lanjut usia.

10) Kunjungan rumah oleh kader disertai petugas bagi anggota kelompok lanjut usia yang tidak datang, dalam rangka kegiatan perawatan kesehatan masyarakat (Public Health Nursing).

Berdasarkan teori di atas, maka penting sekali bagi kita selaku tenaga kesehatan untuk terus mendorong dan memotivasi lansia untuk bisa memanfaatkan posyandu lansia tersebut yang kemudian untuk para kader harus dipikirkan bagaimana mengoptimalkan peranan posyandu lansia sesuai dengan pedoman yang dikeluarkan oleh Kemenkes.

Diharapkan dengan diaplikasikannya PROLANIS ini bisa menambah minat masyarakat untuk lebih menjaga kesehatan mereka khususnya dalam pengandalian penyakit Kronis (Hipertensi dan DM) tanpa mengurangi tujuan utama pelakasanaan Posyandu Lansia yaitu Promotif dan Preventif.

\section{SIMPULAN}

1. Evaluasi Input Program Posyandu Lansia di wilayah kerja Puskesmas Rancaekek :

a. Meningkatnya Program Posyandu lansia dalam menjalankan pelayanan kesehatan lansia terlihat dari bertambahnya jumalah kader Posyandu lansia yang datang dan bertambanhya dukungan pembiayaan dalam pelaksanaan Posyandu Lansia dari BPJS Kesehatan dengan Mengaplikasikan PROLANIS.

b. Ketersediaan sumber daya manusia, sarana, prasarana, sumber dana dan prosedural meningkat setelah diaplikasikannya PROLANIS yang terlihat dari lengkapnya sarana dan obat-obatan, bertambahnya SDM khsuusnya tenaga kesehatan dan meningkatnya dukungan dana 
dalam pelaksanaan Posyandu

Lansia.

2. Evaluasi Process Program Posyandu Lansia di wilayah kerja Puskesmas Rancaekek:

a. Kuantitas pelayanan Posyandu Lansia yang belum optimal terlihat dari pelaksanaan posyandu lansia yang belum melaksanakan 10 jenis layanan serta pelaksanaan Posyandu Lansia yang belum menerapkan sistem 5 meja sesuai standar pelaksanaan Posyandu Lansia dari Kemenkes RI.

b. Kualitas pelayanan yang diberikan pada pelaksanaan Posyandu Lansia sudah cukup optimal dan mengalami peningkatan kualitas terlihat dari jenis layanan yang diberikan dilakukan oleh kader yang sudah terlatih dan tenaga kesehatan yaitu bidan dan dokter.

3. Evaluasi Output Program Posyandu Lansia di Kabupaten Bandung :

a. Hasil pelaksanaan Posyandu Lansia yaitu masih kurangnya cakupan kunjungan lansia yang datang pada saat pelaksanaan posyandu lansia walaupun meningkat dengan diaplikasikannya PROLANIS.

b. Dampak pelaksanaan Posyandu Lansia yang mengaplikasikan PROLANIS terlihat dari perubahan perilaku, pengendalian penyakit kronis (Hipertensi dan DM) serta peningkatan kualitas hidup lansia.

\section{SARAN}

\section{Saran Akademis}

a. Perlu dilaksanakan penelitian untuk mengkaji metode paling efektif dalam memunculkan faktor dominan yang mempengaruhi pemanfaatan posyandu lansia

b. Perlu dilakukan penelitian dengan metode kuantitatif dan kualitatif sehingga hasil penelitian yang didapatkan lebih sempurna.

\section{Praktis}

a. Bagi Dinas Kesehatan

1) Melakukan advokasi ke tingkat desa untuk upaya kelengkapan sarana dan prasarana dan kebijakan tentang pembentukan Posyandu lansia minimal setiap RW mempunyai 1 Posyandu Lansia.

2) Kebijakan dalam pemberian reward bagi kader yang aktif.

\section{b. Bagi Puskesmas}

1) Memberikan Penyuluhan tentang tujuan utama posyandu lansia yaitu untuk memelihara dan menjaga kesehatan bukan pengobatan, sehingga lansia akan datang ke Posyandu Lansia 
secara rutin tidak hanya pada saat sakit.

2) Mempersiapkan kelengkapan pelaksanaan Posyandu Lansia engan melengkapi sarana dan obat-obatan, mempersiapkan SDM khusunya kader Posyandu lansia serta membuat dan menjalankan SOP pelaksanaan Posyandu Lansia.

3) Mengoptimalkan kuantitas pelayanan Posyandu lansia dengan selalu melaksanakan 10 jenis layanan posyandu lansia dan menggunakan tahapan 5 meja dalam pelaksanaan posyandu lansia serta meningkatkan kualitas pelayanan yang diberikan pada pelaksanaan posyandu lansia dengan mengoptimalkan jenis pelayanan posyandu lansia.

4) Melakukan peningkatan kemitraan dengan kepala desa, ketua RW, tokoh masyarakat dengan mengajak mereka bersama untuk memanfaatkan Posyandu lansia setiap bulannya.

5) Memberikan Penyuluhan tentang pengendalian penyakit kronis (Hipertensi dan DM) kepada lansia untuk meningkatkan derajat kesehatan lansia.

\section{DAFTAR PUSTAKA}

Biro Pusat Statistik. Survey Demografi dan Kesehatan Indonesia, BPS. Jakarta;2009.

Budi, T.W.R., 1996 , Model Pelayanan Kesehatan Usia Lanjut Oleh Masyarakat (Penelitian Kualitatif di Kec. Tomohon, Sulawesi Utara), Jurnal Jaringan Epidemologi Indonesia, Vol. 1, Edisi 1, Yakarta.

Burhan, (2003). Analisis data penelitian kualitatif. Jakarta : Raja Grafindo Persada

Burhan, (2007). Penelitian kualitatif. Jakarta : Prenada Media Group

Camacho, G.B and Bixby, L.R, (2009). Differentials by Socioeconomic Status and Institutional Characteristics in Preventive Service Utilization by Older Persons, Journal Aging Health 21 ; 730

Creswell, John W. (2010). Research Design Pendekatan Kuantitatif, Kualitatif dan Mixed. Yogyakarta: Pustaka Pelajar

Departemen Kesehatan Republik Indonesia. Kemitraan dalam Pemberdayaan Masyarakat. Jakarta: Puspromkes Depkes RI;2008

Depkes RI., (2002), Pedoman Pengelolaan Kegiatan Kesehatan di Kelompok Usia Lanjut, Jakarta

Depkes RI., (2005), Pedoman Pembinaan Kesehatan Usia Lanjut Bagi Petugas Kesehatan I, Kebijaksanaan Program, Departemen Kesehatan RI

Federman, A.D, Pendrod, J.D, Livot, E, Hebert P, S, Doucette, J, and 
Siu, A.L, 2010. Development of and Recovery From Difficulty Wityh Activities of Daily Living : An Analysis of National Data. Journal Aging Health $22 ; 1081$

Fuad, H., (2008). Study Fenomenologi Motivasi Lansia Dalam Memanfaatkan Posyandu Lansia Di Kelurahan Sidomulyo Kec. Motesih Kab. Karang Anyar, Program Study Ilmu Keperawatan Fakultas Kedokteran Universitas Diponegoro.

http://datakesra.menkokesra.go.id/sites/d efault/files/pendidikan_file/human development_index_2011.pdf

Kelana. (2011). Metodologi Penelitian Keperawatan. Jakarta : Trans Info Media

Kementerian Kesehatan Republik Indonesia. Pedoman Pembinaan Kesehatan Lanjut Usia Bagi Petugas Kesehatan, Direktorat Bina Kesehatan Komunitas, Jakarta:2010.

Kementerian Kesehatan Republik Indonesia. Pedoman Pengelolaan Kegiatan Kesehatan di Kelompok Lanjut Usia, Direktorat Bina Kesehatan Masyarakat, Jakarta;2010.

Kementerian Kesehatan Republik Indonesia. Pedoman Puskesmas Santun Lanjut Usia Bagi Petugas Kesehatan, Direktorat Bina Kesehatan Masyarakat, Jakarta;2010.

$\begin{array}{ccc}\text { Kementerian } & \text { Kesehatan } & \text { Republik } \\ \text { Indonesia. } & \text { Pusat } & \text { Promosi } \\ \text { Kesehatan. } & \text { (online diakses 20 } \\ \text { Oktober } & \text { 2014). } & \text { Dari } \\ \text { http://www.promkes.depkes.go.i } \\ \underline{\mathrm{d} /}\end{array}$

Komnas Lansia. Pedoman Pelaksanaan Posyandu Lanjut Usia. Komnas Lansia. Jakarta;2010.

Martha, J.W., 1996. Konsep Pembinaan Program Kesehatan Usia Lanjut di Puskesmas, Medika, No. 1, Tahun XXII.

Ropei, O. (2010). Pengalaman

Perubahan Fungsi Seksualitas

Pada Lanjut Usia Di Kota Cimahi Studi Fenomenologi. Tesis UI. lib.ui.ac.id/file?file=digital/137163.. .pdf 13 jan 15

SIRUSA. Usia Harapan Hidup Rakyat Indonesia ; (diunduh 18 Oktober 2014). Tersedia dari :

Sugiyono. (2012). Metode Penelitian Kombinasi (Mixed Methods). Bandung: Alfabeta

Suroyo. (2007). Pengembangan Pola Manajemen Pengelolaan Upaya kesehatan Kerja Di Puskesmas Kota Tasikmalaya.Tesis UNDIP. pola manajemen >>suroyo >>diakses $\operatorname{tg} 22$ des 14

Yati, Imami N.R. (2014). Metodologi Penelitian Kualitatif dalam Riset Keperawatan. Jakarta : Raja Grafindo

Yin, Robert K. (2013). Studi Kasus Desain \& Metode. Jakarta: PT Raja Grafindo Persada 